\title{
JUDGE DECISION AS AN ENGINEERING TOOL IN THE PREVENTION OF CORRUPTION AND MONEY LAUNDERING
}

\author{
Oly Viana Agustine \\ Center of Research and Assessment of Indonesia Constitutional Court \\ E-mail: olyve_lovelaw@yahoo.co.id
}

\author{
ARTICLE INFORMATION \\ Article history: \\ Received July 31, 2015 \\ Revised December 03, 2015 \\ Accepted Febraury 06, 2016

\section{JEL Classifications} \\ K29
}

\section{Key Words:}

Judge Decision,

Engineering Tool,

Corruption and Money Laundering

\section{DOI:}

10.21532/apfj.001.16.01.01.09

\begin{abstract}
Preventing corruption and money laundering requires extra facilities and infrastructure, especially in the process of prosecution. Various measures have been taken by government to eradicate corruption and money laundering. Starting from anti-corruption education to the threat of death penalty for the convicted of corruption have been formulated and implemented in the Indonesian legislation. These measures, however, have not been able to provide maximum results in eradicating corruption and money laundering. Therefore, there should be several alternatives in preventing such cases by enhancing the effectiveness of the existing efforts, one of which is through judge decision. Judge decision, better known as one of the prosecution efforts, can also be made as an engineering tool to prevent corruption and money laundering. This can be seen in the Constitutional Court Decision that provides requirement restriction to the individual candidate for Regional Representative Council (DPD), House of Representatives (DPR), Regional House of Representatives either Provincial, Regency or City, regional head and deputy regional head and for ex-convict with the threat of 5 (five) years imprisonment or more, including corruption and money laundering. In addition, the United Nations Convention Against Corruption (UNCAC) has also provided guidelines on the decision against unauthorized wealth.
\end{abstract}

\section{INTRODUCTION}

\section{A. Background}

Corruption is a serious problem that has not been resolved until this day. The development of corruption is so alarming that it can threaten the stability and security 
of national and international communities. In addition, this crime not only weakens institutions and values of democracy and justice, but also endangers sustainable development and law enforcement (Romli A, 2004). Various efforts have been taken by government, law enforcers, and public in the scope of prevention and prosecution. Preventive measures have been made by conducting cooperation with various related parties to bring awareness to the public about the danger and the consequence of corruption.

In prosecution process, the selection of sanctions contained in the legislation has reached to the maximum with the inclusion of death penalty for the corruptor under certain circumstances, as set forth in Article 2 paragraph (2) of Law No. 31 of 1999 jo. Law No. 20 of 2001 on Corruption Eradication. But these efforts still require reflection and followup related to the effectiveness of existing corruption prevention efforts and ideas or new ideas that need to be raised in order to make the prevention of corruption in Indonesia more effective.

Judge Decision, as the prosecution effort to eradicate corruption and money laundering, is found to have a dual role, as an engineering tool in the prevention and eradication of both corruption and money laundering. It can be seen in the Constitutional Court Decision Number 4 / PUU-VII / 2009 that provides requirement restriction to the individual candidate for the Regional Representatives Council (DPD), the House of Representatives (DPR), the Regional House of Representatives
(DPRD) either provincial, regency or city, as well as candidates for regional head and deputy regional head and for ex-convict with the threat of 5 (five) years imprisonment or more, including corruption and money laundering, in which the Court provides cumulative requirements, such as : (i) does not apply to elected Officials; (ii) the period is limited to five (5) years after the convict finished serving his sentence; (Iii) excluded for ex-convict who openly and honestly tell the public that the concerned is an ex-convict; (Iv) not as repeated crime perpetrators. The Court Decision, both directly and indirectly, has become an engineering tool in eradicating corruption for those who want to register as candidates for the members of Regional Representatives Council (DPD), the House of Representatives (DPR), the Regional House of Representatives (DPRD) either provincial, regency or city, as well as candidates for regional head and deputy regional head.

The Constitutional Court Decision has provided an engineering within a mechanism of public office fulfillment in order not get involved or commit a crime with a minimum penalty of 5 years imprisonment, including corruption.

In addition, within the United Nations Convention Against Corruption (UNCAC) also determines on how a Court Decision executes non-conviction based / NCB asset forfeiture. Such provision has been ratified by the Indonesian government but not yet implemented. If this provision can be executed, the Court Decision in the form of non- 
conviction based / NCB asset forfeiture can be made as an engineering tool in preventing money laundering, in which the proceeds of corruption can be confiscated by the state so that the assets or proceeds of corruption cannot be transferred to other people.

Based on a number of backgrounds mentioned above, the authors are interested in writing an idea in this study entitled "Judge Decision as an Engineering Tool in the Prevention of Corruption and Money Laundering".

\section{B. Problem Formulation}

How can Judge Decision become an engineering tool in the prevention of corruption and money laundering?

\section{RESULTS OF THE STUDY}

\section{A. Judge Decision as an Engineering Tool in} the Prevention of Corruption and Money

\section{Laundering}

Constitutional Court Decision No. 4 / PUUVII / 2009 provides a legal politics for those who have ever been sentenced to prison by the verdict attaining permanent legal force for committing a criminal offense punishable by maximum imprisonment of five (5) years or more. The Court Decision is based on the norm of Article 12 letter $g$ and Article 50 paragraph (1) letter $g$ on General Election Law, and Article 58 letter f on Local Government Law regulating one of the requirements to be able to participate formally in government by requiring "never been sentenced to prison by the verdict attaining permanent legal force for committing a criminal offense punishable by maximum imprisonment of five (5) years or more."

The criminal sanctions as stipulated in the Criminal Code of Indonesia (KUHP) are classified into two (2) types, namely principal punishment and additional punishment. One type of additional punishment is the revocation of certain rights. The revocation of certain rights includes and not limited to the right to vote, either active (to vote) or passive (to be voted), and applies universal principle in which the revocation of the right to vote must be made by court through a verdict attaining permanent legal force (vide Court Decision Number 011017 / PUU-I / 2003). The Constitutional Court Decision Number 4 / PUU-VII / 2009 provides requirement restriction to the individual candidate for the Regional Representatives Council (DPD), the House of Representatives (DPR), the Regional House of Representatives (DPRD) either provincial, regency or city, as well as candidates for regional head and deputy regional head and for ex-convict with the threat of 5 (five) years imprisonment or more, including corruption and money laundering, in which the Court provides cumulative requirements, such as : (i) does not apply to elected Officials; (ii) the period is limited to five (5) years after the convict finished serving his sentence; (Iii) excluded for ex-convict who openly and honestly tell the public that the concerned is an ex-convict; (Iv) not as repeated crime perpetrators. The Court Decision, both directly and indirectly, has become an engineering tool in eradicating corruption for those who want to register as the public official. 
The consideration of Constitutional Court by including the requirement of having never been sentenced to prison by the verdict attaining permanent legal force for committing a criminal offense punishable by maximum imprisonment of five years or more as one of the requirements to hold position in public office is the public trust requirement that is deemed to have the generally accepted practice and there is a certain moral standard which is required for every person who would hold any public office, in which they have never been convicted.

Certain moral standard, which requires that anyone who will hold office in the government is never convicted as stated in the Court Decision, can be made as an engineering tool in the prevention of corruption and money laundering. This decision, directly or indirectly, provides restrictions to those who have ever been convicted, in which their rights to be the candidates for the Regional Representatives Council (DPD), the House of Representatives (DPR), the Regional House of Representatives (DPRD) either provincial, regency or city, as well as the candidates of regional head and deputy regional head are delayed or restricted. And they have to qualify the quo decision.

The quo decision will indirectly give a teaching in social life not to commit an offense punishable by five (5) years, in this case, including corruption and money laundering in order to be able to compete in filling the public office.

No doubt that public office is a strategic position in the fulfillment of economic, social, political and cultural rights of each individual.
The position is, therefore, contested by many parties. The existence of the Court Decision makes the person, who wants to run for public official, not commit criminal acts (corruption) in which the threat complies with the requirements stipulated in the Court Decision.

Continuous teaching of norms on the requirement restriction for those who will run for public officials as stipulated in the Court Decision will become a state administration convention that can undertake engineering on the availability of candidates for public officials (election of members of Regional Representatives Council, House of Representatives, Regional House of Representatives, either provincial, regency or city, as well as the candidates of regional head and deputy regional head) and improve the effectiveness in the prevention of corruption.

Basically, the norm of requirements restriction for candidates who will fill in the public office is not limited only in filling the positions of the government. The provisions have also been widely adopted in some legislations such as Law No. 24 of 2003 regarding the Constitutional Court, Law No. 3 of 2009 on the Second Amendment to Law No. 14 of 1985 regarding the Supreme Court, Law No. 42 of 2008 on the Election of President and Vice President, Law No. 15 of 2006 regarding the Financial Investigation Bureau (BPK), Law No. 18 of 2003 regarding Advocates, Law No. 2 of 2002 regarding the National Police, Law No. 22 of 2004 regarding Judicial Commission and some other legislations. 
One of the requirements that have been determined by Constitutional Court is a mechanism for the convict to tell the public openly and honestly that the person concerned is a former convict. In a study of the reaction to crime, there is a theoretical explanation of the role to make the perpetrator ashamed for the purpose of re-integrating himself with the community. The theoretical explanation is called Reintegrative Shaming. The perpetrator is just made ashamed, but it is intended to make himself and the public aware of the mistakes they have made. In the context of the typology of crime, not all types of crimes can be overcome in this way, because some types of crimes require further recovery efforts, either in the fulfillment of justice or the recovery in the context of restitution and compensation for the victims. But the main requirements for the effectiveness of reintegrative shaming is the willingness of the public to forgive after being humiliated and re-accept the perpetrators.

The provision, in which the convict should tell the public openly and honestly that the person concerned is a former convict in the case of corruption, will make the perpetrator of corruption embarrassed. The provision stipulated in the Court Decision is in line with the efforts of Corruption Eradication Commission (KPK) that require the suspected of corruption to wear special clothing. Both of these provisions are good engineering tools for the society in order not to do anything embarrassing, such as corruption.

\section{B. Judge's Decision as an Engineering Tool in the Prevention of Money Laundering}

Prosecution of wealth is not something new. In the United States, the first implementation of the Law on Anti-Money Laundering has put the government against the unclaimed funds of millions of dollars. With the terminology of illicit enrichment, the United Nations Convention Against Corruption (UNCAC) has recommended criminal prosecution against unexplained assets of public officials, either acquired legally or illegally. Since 1996, the Inter American Convention against Corruption has even known the same terms as UNCA. ${ }^{1}$

Theft of public assets is a big scale of problem in the development. The exact value stolen from the state assets is difficult to determine. From \$ 1 trillion to $\$ 1.6$ trillion loses each year as a result of a variety of illicit activities. ${ }^{2}$ Corrupt public officials in developing countries and transition countries loot as much as $\$ 40$ billion annually, concealing these funds overseas, in which the funds are very difficult to regenerate. This figure is equivalent to the GDP of the 12 poorest countries in the world, where 240 million people live. ${ }^{3}$

http://doa-bagirajatega.blogspot.com/2013/03/
memidana-kekayaan-koruptor-febri.html accessed
on October 6, 2015
UNODC and Bank Dunia, Stolen Asset Recovery
(STaR) initiative: Tantangan, Peluang, dan
Rencana Tindak (Bank Dunia, Washington DC,
2007) p. 10 citing Raymond Baker, Capitalism's
Achilles Heel: Dirty Money and How to Renew the
Free Market System (Hoboken, NJ: John Wiley \&
Sons, Inc., 2005). For initiative text report of STaR
in Greenberg, Theodore S, Linda M. Samuel, et
all, Stolen Asset Recovery: Good Practice Guide
Untuk Perampasan Aset Tanpa Pemidanaan
(Non-Conviction Based/NCB Asset Forfeiture,
(Washington DC, USA: World Bank, 2009). p. 7.
Greenberg, Theodore S, Linda M. Samuel, et 
The eradication of corruption in Indonesia, especially on the prosecution phase, quantitatively has produced criminal decisions to the corruptors in the form of imprisonment. But on the practical side of asset recovery, Indonesia suffered a setback because the system of prosecution adopted is still struggling about how to imprison people. ${ }^{4}$

The eradication of corruption is considered successful if the two important aspects of the law enforcement process, ie corporal punishment and return of proceeds of corruption, can be guaranteed to the maximum by law enforcement officers. The goal is the presence of deterrent effect on the perpetrators and the inability of the corruptors to enjoy their proceeds of corruption. $^{5}$

The failure to return state losses arising from corruption will have implications for the potential of other crimes, such as money laundering, bank fraud, and others. Therefore, asset recovery is an important issue in the anticorruption agenda, and not marginalized from the discourse of law enforcement in Indonesia.

In the effort of recovering the assets related to corruption, both at home and abroad, it is necessary to realize a mechanism of direct prevention and assets recovery as

all, Stolen Asset Recovery: Good Practice Guide Untuk Perampasan Aset Tanpa Pemidanaan (Non-Conviction Based/NCB Asset Forfeiture, (Washington DC, USA: World Bank, 2009). p. 7.

$4 \quad$ Laporan Penelitian Pelaksanaan Instruksi Presiden No. 9 of 2011 tentang Rencana Aksi Nasional Pencegahan dan pemberantasan Korupsi Tahun 2011, Transparansi International Indonesia, The Global Coalition Against Corruption, p. 20.

5 Loc. Cit. the stipulated in the provisions of UNCAC. Indonesian legislation has not set the execution of foreclosure decision (confiscation) of other countries, especially on the implementation of confiscation without a criminal conviction. ${ }^{6}$

Supreme Court Regulation (Perma) No. 1 of 2013 is a regulation that has been used by law enforcement officials to handle the wealth due to the legal vacuum or incompleteness of procedural law of the implementation of Article 67 of Anti-Money Laundering Law (UU TPPU) regulating the procedural law of wealth handling. This regulation applies to requests for the handling of the wealth proposed by the investigators in the case of an alleged offender can not be found as stipulated in Law No. 8 of 2010 on the Prevention and Eradication of Money Laundering.

The good news is the inclusion of in rem forfeiture into the draft of assets confiscation contained in Article 29, in which in rem forfeiture is the measures of the State to take over the assets through a Court Decision in a civil case based on more accurate evidence that the assets are allegedly derived from criminal act or used for criminal act, mentioning that (1) Assets that may be imposed confiscation are: a. objects or bills of the suspect or defendant in which all or parts of them are allegedly obtained from criminal act or results of criminal act; b. objects that have been used directly to commit a crime or to prepare it. c. objects used to obstruct the investigation of criminal act; $d$. objects specially made or intended to commit a crime; e. Other objects that have a direct or

$6 \quad$ Loc. Cit. 
indirect relationship with the crime committed. f. objects allegedly obtained or derived from illegal activities or to enrich themselves or others unlawfully. g. object as finding items. Under the provision, the confiscation can be made to the wealth allegedly obtained illegally in corruption, so it can be instrument in asset recovery.

In general, there are two types of confiscation that are applied internationally to recover the results and instrumentality of crime (assets used to facilitate a crime, such as a car used to transport drugs). Non-Conviction Based/NBC asset forfeiture and asset of crime forfeiture have the same goal. They are the confiscation of the proceeds and the instrumentality of crime by the State. Both have two sides of the same rational. First, those who conduct illegal activity should not be allowed to benefit the proceeds of crime. The assets of crime should be seized and used to compensate the victims, either the state and individual. Second, the activities must be prevented. Negating the economic benefits from the crime act will shrink the intention to commit a crime in the first degree. The confiscation of instrumentality ensures that such assets will not only be used for the purpose of further crimes, but also as a preventive measure. $^{7}$

The difference between crime forfeiture and $\mathrm{NCB}$ asset forfeiture is in the procedure that is expected to confiscate the assets. The main difference between the two is that the asset of crime forfeiture requires a criminal court and

Greenberg, Theodore S, Linda M. Samuel, et all, Stolen Asset Recovery: ... Op. Cit.. hlm. 13. punishment, but NCB asset forfeiture does not. In addition, there are a number of procedural differences that generally characterize the two systems. ${ }^{8}$

Crime forfeiture is an order in personam, an action toward an individual (for example: state against john smith). This requires the criminal court and sentencing and often becomes part of the sentencing process. Some jurisdictions apply a lower standard of proof (ie balance of probabilities) to the forfeiting process compared to the process of parts of the crime act. Nevertheless, the requirement of a criminal conviction is that the government must first assigns guilt "beyond reasonable doubt" or such that the judge "can really be trusted". The system of crime confiscation can be based on object, which means that the authorized prosecutors shall prove that the assets in question are the proceeds or instrumentality of crime. As an alternative, can also be a regime that is based on values which allow the confiscation in line with the benefits to offenders of this crime, without proving the relationship between crime and the object of such assets. ${ }^{9}$

The differences between crime asset forfeiture and $\mathrm{NCB}$ asset forfeiture are $:^{10}$

\begin{tabular}{ll}
\hline 8 & Loc. Cit. \\
9 & Loc. Cit. \\
${ }_{10}$ & Ibid., hlm. 14.
\end{tabular}




\begin{tabular}{|c|c|c|}
\hline Difference & Confiscation of Crime Assets & Confiscation of NCB Assets \\
\hline Action & $\begin{array}{l}\text { in personam as part of criminal charges } \\
\text { on someone. }\end{array}$ & $\begin{array}{l}\text { in rem, judicial action filed by the } \\
\text { government against the goods. }\end{array}$ \\
\hline When it happens & $\begin{array}{l}\text { Imposed as part of a sentence in a } \\
\text { criminal case }\end{array}$ & $\begin{array}{l}\text { Filed before, during or after a } \\
\text { criminal sentence or even with the } \\
\text { absence of criminal charges }\end{array}$ \\
\hline Proving unlawful acts & $\begin{array}{l}\text { The need for criminal penalties, shall } \\
\text { assign the criminal activities "beyond } \\
\text { reasonable doubt" or "with earnest } \\
\text { belief" }\end{array}$ & $\begin{array}{l}\text { Criminal sentence is not necessary, } \\
\text { shall assign the unlawful act based } \\
\text { on the standards of proof "balance } \\
\text { of probabilities" }\end{array}$ \\
\hline $\begin{array}{l}\text { Linkage between results } \\
\text { and unlawful acts }\end{array}$ & Based on object and value & Base on object \\
\hline Confiscation & $\begin{array}{l}\text { Confiscating the interests of the } \\
\text { defendant in assets }\end{array}$ & $\begin{array}{l}\text { Confiscating the object itself, in case } \\
\text { the owner is not guilty }\end{array}$ \\
\hline Jurisdiction & Different (criminal or civil) & Different (criminal or civil) \\
\hline
\end{tabular}

$\mathrm{NCB}$ asset forfeiture, also referred to as "civil forfeiture", "in rem forfeiture" or "objects forfeiture" in some jurisdictions, is an action toward the asset itself and not to an individual. This is an action that is separate from any criminal proceedings and requires proof that the asset has been contaminated in which the asset is the proceeds or instrumentality of crime. In general, unlawful acts shall be determined on the basis of the standard of proof, balance of probabilities. This reduces the burden of government and means that there is the possibility of obtaining confiscation when there is not sufficient proof to support a criminal prosecution. Therefore, the actions are not against an individual defendant but against the assets, the assets owners are the third parties who are entitled to retain such assets. ${ }^{11}$

NCB asset forfeiture is useful in many contexts, especially when crime forfeiture is not possible or not available, because: ${ }^{12}$

a. The offender is a fugitive. Criminal punishment is not possible if the

\begin{tabular}{ll}
\hline 11 & Loc. Cit. \\
12 & Ibid., hlm. 15.
\end{tabular}

defendant is a fugitive.

b. The offender has died before a judgment. Death ends a criminal judicial process.

c. The offender is in such a reign that investigation or criminal prosecution is not realistic or impossible.

d. The offender is unknown and his asset is found (via courier who is not involved in criminal offenses). If the asset is derived from a crime, the owner or offender may be unwilling to face the civil judicial process of recovery, worried because this will lead to a criminal prosecution. Such doubt complicates the criminal prosecution against the offender, or even impossible.

e. Related asset is held by a third party who is not charged with a felony offense, but he realizes that the asset has been contaminated. Although crime forfeiture cannot achieve the asset held by a bona fide third party, NCB asset forfeiture may confiscate the asset of a third party without a bona fide defense. 
f. There is no adequate proof to continue the criminal prosecution.

NBC asset forfeiture is indeed possible because it is an in rem action against the assets, not against the person, or criminal punishment is not a condition, or both. NBC asset forfeiture is also useful for the following circumstances: ${ }^{13}$

a. The offender has been exempted from the basic criminal offense due to a lack of evidence that can be used or a failure to meet the burden of proof. It applies in jurisdictions in which the NCB asset forfeiture is set on a standard of proof that is lower than the standard of criminal punishment. Although there is a possibility that the proof is insufficient for a criminal punishment without a decent doubt, but there is a possibility of a viable evidence to show that the asset is derived from illicit activities on the basis of the balance of probabilities..

b. The forfeiture is not at issue. In jurisdictions in which the NCB asset forfeiture is carried out as civil judicial process, default judgment procedure is used to confiscate the asset, resulting in time and cost efficiency..

NCB asset forfeiture can effectively return such funds to the citizens who become victims. Although the $\mathrm{NCB}$ asset forfeiture may never be used as a substitute for criminal prosecution, in many cases (especially in the context of corruption by officials), the NBC asset forfeiture may be the only tool available

13 Loc. Cit. to recover the proceeds of crime and to obtain justice. Since the regime of NCB asset forfeiture does not rely on a criminal judgment, it can be continued regardless of the death, fugitive, or any immunity that may be enjoyed by the corrupt officials. $^{14}$

NCB asset forfeiture does not predetermine or preclude any release or use of the assets seized. The confiscated asset will be released by jurisdiction that has confiscated it, as stipulated by legislation. However, the international treaties can establish different levels of liability for such legislation regarding the final release of asset, according to the type of fundamental breach. ${ }^{15}$

The provisions of asset recovery contained in several United Nations Conventions are:

a. The United Nations Convention Against Corruption (UNCAC) article 57

3... The requested state party shall:

(a) In the case of public funds embezzlement or public funds laundering of the proceeds of embezzlement ... returns the confiscated asset to the requesting country.

(b) In the case of the proceeds of other offenses covered by this Convention ... returns the confiscated asset to the requesting country, when the requesting country decently assigns the prior ownership of the confiscated asset to the requested country or when the the requested

\footnotetext{
$14 \quad$ Ibid., hlm. 15-16.

$15 \quad$ Ibid., hlm. 23.
} 
country recognizes the loss of the requesting country as a base to return the confiscated asset.

(c) In other cases, gives priority to consideration to return the confiscated asset to the requesting country, returns such asset to the prior legitimate owners or to compensate any victims of crime.

4... Where feasible, the countries may also give special consideration to finalize agreements or arrangements mutually agreed on a case-by-case basis, for the final release of confiscated asset.

b. The United Nations Convention Against Transnational Organised Crime (UNTOC) Article 14

1. Proceeds of crime or the asset confiscated by one country ... will be released by the country in accordance with National Laws and the administrative procedures.

2. When acting in accordance with the request made by other countries ... the countries will, to the extent permitted by national law and if so requested, give priority consideration to return the proceeds of crime or confiscated asset to the requesting country so as to be able to give compensation to the victims of crime or to return the proceeds of crime or such asset to the rightful owner.

3. When acting in accordance with the request made by the other countries
... one of the parties may give special consideration to finalize agreements or arrangements:

(a) Giving contribution as much as the proceeds of crime or the asset derived from the sale of such proceeds of crime or property or a part thereof to the account designated in accordance with Article 30, paragraph 2 of letter $\mathrm{C}$ of this convention (an account for technical assistance) and to the inter-governmental agencies that specifically fight against organized crime.

(b) Sharing with the parties of other countries, on a case-by-case basis at regular intervals, proceeds of crime or assets or funds derived from the sale of proceeds of crime or such property, in accordance with national law or the administrative procedures.

c. Article 5 of Vienna Convention states that:

(a) Proceeds or property confiscated by one of the parties ... will be released by the party concerned in accordance with national laws and administrative procedures.

(b) When acting in accordance with the request of the other party ... the party can give special consideration in completing agreements on: (iii) contribute the same value as the proceeds 
and asset or funds derived from the sale or the asset, or a substantial portion thereof, to the inter-governmental agencies specialized in eradicating illicit trafficking and abuse of narcotic and psychotropic substances.

(c) Sharing with the parties of other countries, on a case-by-case basis at regular intervals, proceeds of crime or assets or funds derived from the sale of proceeds of crime or such property, in accordance with national law or the administrative procedures, or bilateral or multilateral agreements held for this purpose.

Removing a criminal prosecution from the confiscation of NCB asset forfeiture impairs the effectiveness of criminal law and public trust in law enforcement. Therefore, although the $\mathrm{NCB}$ asset forfeiture can be an effective tool for recovering assets related to crime, the NCB asset forfeiture is not used as an alternative for criminal prosecution when a jurisdiction has the ability to take action against the offender. In other words, criminals should not be allowed to avoid prosecution by pointing to the NCB asset forfeiture regime as a mechanism for the effort to replace the crime that has been committed. Negating the prosecution of crimes, when there is, by being replaced with NCB asset forfeiture looks as if the offender can buy the way out of prosecution. In general, the reduction of crime should be obtained through prosecution, penalty, punishment and confiscation. So, the criminal prosecution shall be pursued as far as possible to avoid the risk that the prosecutors, the courts and the public will view the outpouring of assets as a sufficient sanction when criminal laws have been violated. ${ }^{16}$

However, the NCB asset forfeiture must complete the criminal prosecution and punishment. It can precede a criminal charge or run parallel with the criminal judicial process. In addition, the choice of assets confiscation shall be maintained in all cases so as to be able to be executed when a criminal prosecution can not be performed (for example, the defendant died, fled from the jurisdiction or immune from prosecution or the offense is immune to the laws) or unsuccessful (for example, the defendant is acquitted or no decent proof for criminal punishment). This principle should be stated affirmatively in the legislation. It should be proven that the asset has been contaminated, which means that such asset is the proceeds of crime or the instrumentality used to commit a crime. ${ }^{17}$

Therefore, the NCB asset forfeiture is triggered by perpetration, there may be some circumstances where the criminal investigation and prosecution collide or run parallel with NCB asset forfeiture. Most of such condition can be anticipated and the legislation should provide a resolution at the time the jurisdiction is deciding the point at which the NBC judicial process is allowed to begin. Jurisdiction will need to decide whether NCB judicial process can be allowed only if the judicial process of

\begin{tabular}{ll}
\hline 16 & Ibid., hlm. 27. \\
17 & Loc. Cit.
\end{tabular}


prosecution and confiscation is not possible, or whether the action of NCB asset forfeiture ${ }^{18}$ and criminal prosecution can run simultaneously.

In cases of drug in Thailand, there is a policy to carry out NBC asset forfeiture simultaneously with the criminal prosecution. ${ }^{19}$ In addition, if there is an acquittal in criminal court, the Drugs Control Board Office and the Royal Thai Police hand over all assets seized or detained to the Anti-Money Laundering Office (AMLO) to conduct judicial proceedings on the confiscation of NBC assets and give AMLO evidence and cooperation in order to obtain the NCB asset forfeiture. Other jurisdictions are also willing to share information among agencies in the legislation of NCB. ${ }^{20}$ Sharing such information is important for the international investigation of the State, and the compliance with international commitments. ${ }^{21}$

Either criminal prosecution or $\mathrm{NCB}$ asset forfeiture can run without violating the protection against the double risk because the NBC asset forfeiture is neither a punishment nor a criminal judicial process. ${ }^{22}$ In the United States vs. Ursery, the US Supreme Court declared cases reviewing civil confiscation based on the clauses of double risk adhering to a very consistent theme ... the NBC asset

\section{$18 \quad$ Ibid. hlm. 28.}

19 Undang-unang Anti Pencucian Uang 1999, Bagian 58.

20 Undang-undang Hasil Tindak Kejahatan 2002 (Kerajaan Inggris), Bagian 436; Undang-undang Pencegahan Kejahatan Terorisme (Am) 1998 Afrika Selatan, Bagian 71; Undang-undang Perbaikan Perdata (Ontario, Kanada), Bagian 19.

21 Greenberg, Theodore S, Linda M. Samuel, et all, Stolen Asset Recovery..., Op. Cit.. hlm. 29.

22 Loc. Cit. forfeiture or in rem is a remedial civil sanction. It is different from the civil penalty in personam which has the potential to be as a punishment, such as fines and not as a punishment based on the clause of double risk. ${ }^{23}$ The Courts in other jurisdictions have reached the same conclusion, or have confirmed that NCB asset forfeiture is not a punishment or a criminal justice process. In Walsh vs. Director of the Assets Recovery Agency, the Northern Ireland Appeals Court stated that the main goal is to recover the proceeds of crime, not to punish the comparison, in the common sense to follow a criminal sanction. $^{24}$

The NBC asset forfeiture should clearly be applied to circumstances in which the assets owner is absent from prosecution. The absence of assets owner may be due to the offender who had died, fled the jurisdiction, or enjoyed immunity against prosecution. Allowing someone to be able to avoid prosecution and maintain his illegal assets (or pass on the assets to his heir in case of death) is a huge incentive for each person who will be the villain. Although the NCB asset forfeiture is seen as something which is compensated in one jurisdiction and as punitive in other jurisdictions, the inability for a prosecution should not affect other legal actions to recover the proceeds and instrumentality of crime..$^{25}$

$23 \quad$ Amerika Serikat lawan Ursery; 518 US. 267, 278 (1996)

24 Walsh lawan Director of The Assets Recovery Agency; (2005) NICA 6 (Pengadilan Banding Irlandia Utara) ayat. 39.

25 Greenberg, Theodore S, Linda M. Samuel, et all, Stolen Asset Recovery..Op. Cit. hlm. 30. 
Some jurisdictions have a different trigger on the action of NCB asset forfeiture of the assets owned by someone who has died. For example, a variety of options includes confiscation permit charged to the deceased if the death occurs after (1) the investigation has been carried out, (2) charges have been imposed, (3) a sentence has been announced. Some jurisdictions impose similar limitation to use NCB asset forfeiture of the assets owned by a fugitive, based on the time the fugitive escapes. The principle is not to limit the enforcement of the law, but to give permission to proceed in rem regardless of when the offender dies or runs away from the jurisdiction. In Philippines, for example, the NBC asset forfeiture is a siu generalis. Anti-Money Laundering Law requires the assets owners that are subject to confiscation to be submitted as a party, however, the judicial process can be carried out in his absence. ${ }^{26}$

Similarly, illicitly acquired assets should not be protected by personal immunity against any prosecution that may be enjoyed by an official. If the official is given immunity because of his diplomatic status or official status, the criminal action of such individual should not be allowed (except in the presence of a waiver of jurisdiction or parliament). The blanket immunity should not protect the assets of corrupt officials from the judicial process of NCB asset forfeiture or investigation. Thus, it is necessary to the provisions that prevent people who claimed immunity from criminal prosecution to give the evidence related to the NCB asset forfeiture action unless there have

26 Loc. Cit. been adequate sanctions. The provisions may deter people who refuse to give evidence in a criminal judicial process to submit evidence related to the NCB asset forfeiture or may order the parties to seek facts to draw the opposite conclusion based on the lack of evidence or consider certain facts as proven. A provision in the NCB asset forfeiture legislation should expressly state that there is no immunity for the assets, and where necessary, jurisdiction should be prepared to issue a diplomatic memorandum requiring that any residual immunity relating to the assets is excluded.

NCB asset forfeiture should also be provided for circumstances where criminal prosecution is not successful, for example, a defendant has been acquitted or the defendant can not be prosecuted because of a lack of evidence to obtain a criminal conviction without reasonable doubt or by a judgment based on convincing evidence. ${ }^{27}$ Liberation can occur with several reasons: the evidence collected in a legitimate search is declared as unacceptable; a witness can retract his testimony; the trial judge may misdirect the jury; a member of the jury can be intimidated into voting not guilty.

Lack of decentr evidence can occur for similar reasons and is often a bitter reality for cases involving corruption and organized crime. However, NCB asset forfeiture systems that apply a lower standard of proof than the standard for criminal punishment (which is not

$27 \quad$ Lihat Assets Recovery Agency lawan Woodstock, (2006) EWCA Civ 741 (kerjaan Inggris) (kurang adanya bukti yang layak adanya pemidanaan setelah saksi utama memulihkan kesaksiannya tidak menghambat perampasan aset NCB) 
always the case in some jurisdiction of civil law), it is likely there is still decent evidence to determine the obligations under this lower standard. ${ }^{28}$

With the existence of NCB mechanism, a judicial action in the form of confiscation of proceeds of crime (in rem) in the case of money laundering filed by the government, can be made as an engineering tool in preventing money laundering. According to the provisions, the confiscation can be made to the assets allegedly obtained illegally in money laundering, so it can be a means in returning stolen assets.

The NCB mechanism will provide learning that those who commit illegal activities should not be allowed to take benefit from the crime. The proceeds of crime should be seized and used to compensate the victims, both the state and the individual. Secondly, the activities must be prevented. Negating the economic benefits of crime will shrink the intention to commit a crime in the first degree. Confiscating the instrumentality ensures that such assets will not be used for the purpose of further crimes, as well as a preventive action. ${ }^{29}$

\section{III.CONCLUSION}

In eradicating corruption and money laundering requires various mechanisms to prevent it. Anti-corruption education and death penalty are appropriate means. But it is inevitable that the two provisions have not been implemented well. Therefore, there should be other mechanism to enhance the effectiveness

28 Greenberg, Theodore S, Linda M. Samuel, et all, Stolen Asset Recovery:... Op. Cit. hlm. 31-32.

29 Ibid., hlm. 13. of judge decision as an engineering tool in the prevention of corruption and money laundering. Constitutional Court Decision No. 4 / PUUVII / 2009 has provided a legal politics for those who have been sentenced to prison by a court decision which has attained permanent legal force for committing a criminal offense punishable by imprisonment of five (5) years or more to restrict their right to run for a public office, by meeting the conditions required by the Constitutional Court, one of which is to announce to the public that he is a convict. In addition to the Constitutional Court Decision, the UNCAC has provided provision on NBC asset forfeiture. NCB asset forfeiture is a judicial action on the proceeds of crime (in rem). The NCB asset forfeiture can be used to provide an engineering to the sentenced person or society that the perpetrators of money laundering will be punished not only on the body but also on the wealth.

\section{REFERENCES}

Greenberg, Theodore S, Linda M. Samuel, et all, 2009, Stolen Asset Recovery: Good Practice Guide Untuk Perampasan Aset Tanpa Pemidanaan (NonConviction Based/NCB Asset Forreiture, (Washington DC, USA: World Bank).

Laporan Penelitian Pelaksanaan Instruksi Presiden No. 9 Tahun 2011 tentang Rencana Aksi Nasional Pencegahan dan pemberantasan Korupsi Tahun 2011, Transparansi International Indonesia, The Global Coalition Against Corruption. 
Romli Atmasasmita, 2004, Strategi dan Kebijakan Pemberantasan Korupsi Pasca-Konvensi PBB Menentang Korupsi Tahun 2003, makalah disampaikan dalam Diskusi Panel "Menjelang Pengadilan Antikorupsi di Indonesia", diselenggarakan oleh British Council, 1516 September, di Jakarta.

UNODC dan Bank Dunia,2009, Prakarsa Pemulihan Aset Curian (STaR): Tantangan, Peluang, dan Rencana Tindak (Bank Dunia, Washington DC, 2007) hal. 10 mengutip Raymond Baker, Capitalism's Achilles Heel: Dirty Money and How to Renew the Free Market System (Hoboken, NJ: John Wiley \& Sons, Inc., 2005). Untuk teks laporan Prakarsa STaR) dalam Greenberg, Theodore S, Linda M. Samuel, et all, Stolen Asset Recovery: Good Practice Guide Untuk Perampasan Aset Tanpa Pemidanaan (Non-Conviction Based/ NCB Asset Forreiture, (Washington DC, USA: World Bank).

\section{LEGISLATIONS AND WEBSITE}

Teks UNCAC, bersama dengan daftar negaranegara yang telah menandatangani atau meratifikasinya, tersedia di http://www. unodc/en/treaties/CAC/index.html.

Undang-undang Anti Pencucian Uang 1999

Undang-undang Hasil Tindak Kejahatan 2002 (Kerajaan Inggris)

Undang-undang Pencegahan Kejahatan Terorisme (Am) 1998 Afrika Selatan
Undang-undang Perbaikan Perdata (Ontario, Kanada)

The Scottish Ministers lawan Doig, (2006) CSOH 176 (Skotlandia)

Walsh lawan Director of The Assets Recovery Agency; (2005) NICA 6 (Pengadilan Banding Irlandia Utara)

Director of The Assets Recovery Agency lawan Tand other (2004) EWHC 3340 (kerajaan Inggris)(pembebasan dari pencucian uang dengan alasan pengungkapan tidak menghambat perampasan aset $\mathrm{NCB}$ terhadap dana)

National Director of Public Prosecutions lawan, (2006) ZACC 17 (pembebasan atas tuntutan perdagangan narkotika tidak menghambat perampasan aset NCB terhadap tempat tinggalnya)

Assets Recovery Agency lawan Woodstock, (2006) EWCA Civ 741

http://doa-bagirajatega.blogspot.com/2013/03/ memidana-kekayaan-koruptor-febri. htmldiakses pada tanggal 06 April 2013 
Oly Viana Agustine : Judge Decision As An Engineering Tool In The.....

Page 113-128 